\title{
The effect of a lack of uncapped brood on social interactions between honey bee workers and the queen
}

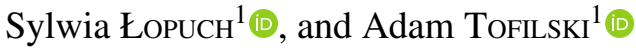 \\ ${ }^{1}$ Department of Zoology and Animal Welfare, Faculty of Animal Science, University of Agriculture in Krakow, Al. 29 \\ Listopada 54, 31-425 Krakow, Poland
}

Received 18 June 2021 - Revised 23 September 2021 - Accepted 1 November 2021

\begin{abstract}
Vibro-acoustic communication is used by honey bees in many different social contexts. Our previous research showed that workers interact with their queen outside of the swarming period by means of wing-beating behaviour. Therefore, the aim of this study was to verify the hypothesis that the wing-beating behaviour of workers attending the queen stimulates her to lay eggs. The behaviour of workers and the queen was recorded using a high-speed camera, at first in the presence of uncapped brood in the nest and then without one. None of the queens performed wing-beating behaviour. On the other hand, the workers attending the queen demonstrated this behaviour two times per minute, on average, even in the presence of uncapped brood in the nest. After removing the combs with the uncapped brood, the incidence of wing-beating behaviour increased significantly to an average of four times per minute. Wing-beating behaviour did not differ significantly in its characteristics when uncapped brood was present or absent in the nest. During 3 days after removing the combs with the uncapped brood, there was no significant increase in the rate of egg lying by the queen. Therefore, the results presented here do not convincingly confirm that the wing-beating behaviour of workers affects the rate of queen's egg-lying. This negative result can be related to colony disturbance and longer time required by the queen to increase egg production.
\end{abstract}

egg-laying rate / high-speed camera / honey bees / social interactions / uncapped brood / wing-beating behaviour

\section{INTRODUCTION}

The western honey bee (Apis mellifera) is a highly social species which forms colonies consisting of thousands of cooperating individuals. Their cooperation can only be productive if they effectively communicate with each other. Most of the interactions between honey bees occur inside the nest in darkness, where visual communication is not possible. In this situation, their communication is mainly based on chemical (for review see

Corresponding author: S. Łopuch,

Sylwia.Lopuch@urk.edu.pl

Manuscript editor: David Tarpy
Slessor et al. 2005; Alaux et al. 2010; Richard and Hunt 2013; Bortolotti and Costa 2014) and vibro-acoustic (for review see Kirchner 2006; Hrncir et al. 2006; Hunt and Richard 2013) signals. However, the latter form of communication is still poorly understood.

The known vibro-acoustic signals include queen piping (Wenner 1962a; Grooters 1987; Michelsen et al. 1986b), worker piping (Ohtani and Kamada 1980; Pratt et al. 1996; Seeley and Tautz 2001; Schlegel et al. 2012), stop signal (Michelsen et al. 1986a; Nieh 1993; Schlegel et al. 2012), buzz-run signal (Rangel and Seeley 2008; Rittschof and Seeley 2008), waggle dance vibrations (Wenner 1962b; Wenner et al. 1967; Michelsen et al. 1986a, 1987; Waddington and 
Kirchner 1992; Seeley and Visscher 2008) and a shaking signal (also called vibration signal; Allen 1958, 1959; Ghal 1975; Painter-Kurt and Schneider 1998a, b). Most of these signals (except the shaking signal) are generated by rapid contractions of the antagonistic flight muscles. The thoracic vibrations are transformed into substrate vibrations and airborne sounds. These vibrations can be also transmitted directly by pressing the thorax against another bee (Simpson 1964; Esch and Wilson 1967; Michelsen et al. 1987; Tautz 1996; Seeley and Tautz 2001; Hrncir et al. 2008). The shaking signal, by contrast, is produced by a worker rapidly vibrating her body dorso-ventrally whilst grasping another bee or a queen cell (Ghal 1975).

The vibro-acoustic signals were mostly studied with the use of microphones (Wenner 1962a, b, Wenner et al. 1967; Ohtani and Kamada 1980; Michelsen et al. 1986a, b, 1987; Pratt et al. 1996; Seeley and Tautz 2001) and less often using laser vibrometers (Michelsen et al. 1986a, b; Hrncir et al. 2008) or accelerometers (Ramsey et al. 2017, 2020). However, our previous research (Łopuch and Tofilski 2017a, b, 2019, 2020) proved that recording honey bee behaviour with a high-speed camera is a simple and useful alternative. This technique allows to observe high-frequency vibro-acoustic signals produced by flight muscles. The contractions of the flight muscles induce oscillations of the wings (Hrncir et al. 2008). As frequency of these oscillations is relatively high $(100-500 \mathrm{~Hz})$, they cannot be observed with the naked eye. However, when high-speed recording is played at low speed, the oscillations of wings called wing beats (Łopuch and Tofilski 2017a) are clearly visible (Online Resource 1). Wing beats were detected during stop signal, buzz-run signal, queen and worker piping signals (Łopuch and Tofilski 2019) and waggle dance (Łopuch and Tofilski 2017a, b, 2020). The high-speed video recording allows to detect a source of vibro-acoustic signal among a large group of bees in the nest, and it provides information about the behaviour of a vibrating bee and its surroundings. Using high-speed video recording, it is possible to precisely analyse and measure characteristics of wing vibrations generated by bees including frequency and pulse duration.

It is well known that workers communicate with their queen during swarming (Allen 1958, 1959; Grooters 1987; Painter-Kurt and Schneider 1998a; Pierce et al. 2007). Our previous research showed that workers also generate wing beats in direct contact with the queen outside of the swarming period (Łopuch and Tofilski 2019); however, the meaning of those interactions remains unknown. Outside of the swarming period the two main tasks of the queen are egg laying and production of pheromones. The pheromones inform colony members about presence of the queen and elicit retinue formation (Slessor et al. 2005). They are probably produced at a constant rate, and it seems unlikely that workers are involved in regulation of their production. On the other hand, the egg-laying rate changes over year (Koeniger 1986) and needs to be adjusted to colony capability. Therefore, it is more likely that the wing-beating behaviour of workers in the presence of the queen is involved in regulation of her egg production. The mechanism for controlling the queen's egg-laying rate is not well understood. The egg-laying rate may be controlled by the feeding of the queen (Allen 1960) and/or by the rate at which comb cells are prepared for egg deposition (Free and Williams 1972). It was also observed that a queen's egg-laying rate depends on the presence of brood pheromones emitted by developing larvae, which not only increased egg production by the queen but also the queen's feeding time and the time spent by workers cleaning the cells (Sagili and Pankiw 2009). Importantly, the brood pheromones emitted by larvae have many different effects on honey bee colonies, including increasing colony pollen foraging (Metz et al. 2010; Pankiw et al. 1998), initiating foraging by individual workers (Le Conte et al. 2001), brood rearing (Sagili and Pankiw 2009), nursing behaviour (Traynor et al. 2014, 2015), capping of the cell (Le Conte et al. 1990) and suppressing ovary activation in workers (Traynor et al. 2014).

Based on the observations that workers interact with the queen outside of the swarming period (Łopuch and Tofilski 2019), it was hypothesised that the wing-beating behaviour of workers in the presence of the queen is involved 
in regulation of her egg laying. In the present study, therefore, it was predicted that a lack of uncapped brood in the nest will increase the incidence of worker wing-beating behaviour in the presence of their queen, as well as the incidence of egg-laying by the queen. In order to verify this prediction, the behaviour of workers and their queen was recorded in the presence and then in the absence of uncapped brood in the nest.

\section{MATERIALS AND METHODS}

\subsection{Honey bees}

The experiment was performed on three colonies of honey bees housed in the observation hives at the laboratory of the University of Agriculture in Krakow. The observation hives consisted of six frames, two of which were located behind glass walls that allowed the honey bees to be recorded. These two frames were separated from the other frames located above them in the hive body by a queen excluder. The queen was able to move on the two frames, and her interactions with workers could be recorded. Each colony consisted of about 12,000 bees. Neither colony showed any symptoms of diseases or parasites other than a Varroa mite infestation, which was below treatment threshold because it had been controlled by an acaricide in the previous season. The guidelines for the care and use of animals were followed (Guidelines for the use of Animals 2020).

\subsection{Data collection}

During the first 3 days, the behaviour of the queen and the workers was recorded in the presence of brood in all colonies. This was the control phase. On the fourth day of the experiment, the combs with uncapped brood were removed and replaced by combs without brood in all colonies. The behaviour of the queen and workers was continued to be recorded for the next 3 days in the absence of uncapped brood. This was the experimental phase. On the fourth day of the experiment, the bees were recorded approximately 2-3 h after the combs with uncapped brood were removed from the nest so that the bees had time to calm down and return to their activities. Each phase lasted 3 days to collect sufficient data about the behaviour of the queen and the workers and to decrease the potential impact of variability in the bees' behaviour during the experiment, which was performed under managed conditions with one manipulation connected with removal of uncapped brood, but also with bees freely flying in and out of the hive.

The social interactions between the queen and the workers were recorded with a high-speed camera (Phantom MIRO eX4, Vision Research, Inc. USA). A LED lamp (LEDIM616, $50 \mathrm{~W}$, Ledim, Poland) was used as the white light source because it does not emit much heat and does not disturb the behaviour of honey bees by flickering. Videos were recorded with a sample rate of 2000 frames per second (fps) at a resolution of $512 \times 384$ pixels. Each frame lasted $500 \mu \mathrm{s}$, and each recording lasted $7.2 \mathrm{~s}$. The video recordings were made and analysed using PCC software, version 2.6 (Vision Research, 2015).

Video data were collected in June from 10.00 to 16.00. In Colonies A, B and C, a total of 166, 172 and 174 recordings were made, respectively. On each day of the experiment, 29 recordings were made on average in each of the colonies. The interval between two consecutive recordings was 10 to $15 \mathrm{~min}$. In total, there were 512 recordings, and their combined duration was $64.1 \mathrm{~min}$.

\subsection{Data analysis}

In each recording, the queen and the workers surrounding her were visible. We defined workers in direct proximity of the queen with their heads oriented towards her as the queen's retinue. The behaviour of the queen and the workers from her retinue was analysed. In all recordings, the incidence of wing-beating behaviour was determined, calculated as the number of wing-beating behaviours performed during $1 \mathrm{~min}$ by workers from a queen's retinue. As one wing-beating 
behaviour, we counted a worker which produced at least one pulse of wing beating during a recording. The wing-beating behaviour usually consisted of trains (sequences) of wing-beating pulses (also called syllables), where pulses were separated by short intervals (below $1 \mathrm{~s}$ ), when wings were immobile. If intervals between two pulses were longer than $1 \mathrm{~s}$, it was assumed as two trains of pulses. Moreover, if two workers performed this behaviour in one recording, it was counted as two wing-beating behaviours. The recordings were analysed to detect the wing-beating behaviour at the sample rate of 50 fps, which means a 40-fold slower playback in comparison to the recording speed. The detection of wing-beating behaviour in all recordings required $41 \mathrm{~h}$ of playback.

In 111 recordings $(34,31$ and 46 recordings in Colonies A, B and C, respectively), additional detailed analysis of the characteristics of wing-beating behaviour of workers attending the queen was carried out. In some recordings, more than one worker from a queen's retinue performed a wing-beating behaviour; therefore, the total number of analysed behaviours was 136 . The analysis included the frequency of wing beats, the duration of wing-beating pulses and the duration of intervals between wing-beating pulses. The frequency of wing beats was determined as the number of wing beats performed per second, whereas a wing beat was defined as a complete cycle of wing movement up and down. The duration of a wing-beating pulse was determined as the time elapsed between the beginning and the end of a given pulse when a worker performed a wing beat. In turn, the interval between wing-beating pulses was defined as the time elapsed between the end of one pulse and the beginning of a second pulse when the wings were immobile. The analysis of wing-beating was based on 52 wing-beating behaviour incidences performed by workers in the presence of uncapped brood and 84 wing-beating behaviour incidences performed in its absence (in the case of interval duration, the analysis included 49 behaviours with uncapped brood and 81 without). The analysis of the recordings to characterise the wing beating of workers in the presence of the queen was made at a sample rate of $5 \mathrm{fps}$, which equates to a 400-fold slower playback speed. The detailed analysis of the selected 136 behaviours required approximately $108 \mathrm{~h}$ of playback.

The egg-laying rate was determined as the number of eggs laid by a queen in $1 \mathrm{~min}$. The egg-laying rate was estimated based on observations of the queen's behaviour, which lasted 3-5 min and were repeated 5-8 times per day. The observations lasted 140, 130 and $114 \mathrm{~min}$, respectively, in Colonies A, B and $\mathrm{C}$. The total duration of queen observation was $384 \mathrm{~min}$. It was assumed based on observations that a queen laid an egg when she inserted her abdomen in a cell on the comb and remained in this position for 20-30 s.

\subsection{Statistical analysis}

All data were checked for deviation from a normal distribution. In the cases where the distribution was not normal (the interval duration between wing-beating pulses), the analysed data were ln-transformed. Two-way ANOVA was used to compare the incidence of wingbeating behaviour of workers and the egglaying rate of queens in the colonies with or without uncapped brood, including the colony as a factor. Additionally, two-way MANOVA was performed to assess differences in the characteristics of workers' wing beating. A post hoc NIR Fisher test was used for pair-wise comparisons. All tests were two-tailed. The statistical analyses were performed using Statistica, version 13.3 (Statsoft Inc., 2017). The recorded video data were not blinded because the observer was not able to assess the parameters of dances before their precise analysis.

\section{RESULTS}

\subsection{Wing-beating behaviour}

None of the queens moved their wings during all recordings. In turn, the workers attending the queens moved their wings both before and after the removal 


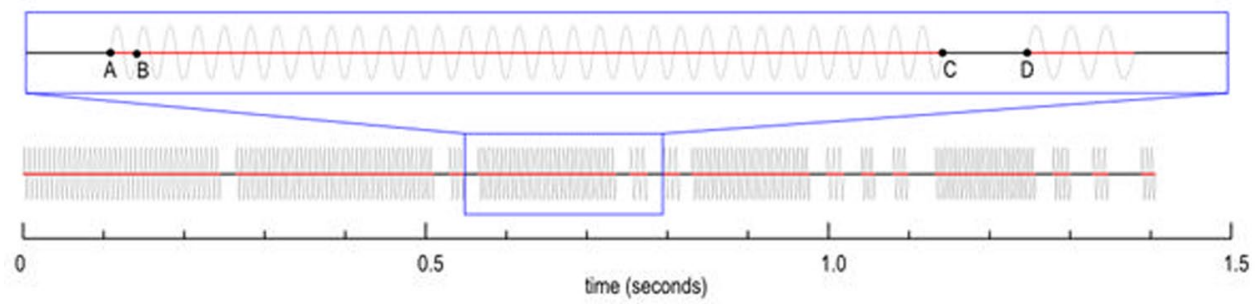

Figure 1. Schematic drawing of wing-beating behaviour performed by a honey bee worker in contact with the queen. Sinusoid line indicates wing movements. One wing beat is between points A and B. One pulse of wing beating is between points $\mathbf{A}$ and $\mathbf{C}$. One interval between pulses of wing beating is between points $\mathbf{C}$ and $\mathbf{D}$. This sequence of wing-beating pulses was preceded and followed by an interval without wing beating lasting more than $1 \mathrm{~s}$.

of combs with uncapped brood (Online Resource 1). The duration of a single wing-beating pulse ranged from 3 to $1017 \mathrm{~ms}$, whereas the duration of a single interval between wing-beating pulses ranged from 0.5 to $4875 \mathrm{~ms}$. The wing-beating pulses usually occurred one after another and formed trains, which were preceded and followed by relatively long intervals of immobile wings (Figure 1). The number of wing-beating pulses in one train ranged from 4 to 70 , whereas the mean duration of one train of pulses was $1.35 \mathrm{~s}$.

\subsection{Incidence of wing-beating behaviour}

In the presence of uncapped brood, wing-beating behaviour was observed in the queen's retinue at least once per minute. Only in Colony B on the third day of observation was this behaviour observed slightly less often (Table I). However, the incidence of wing-beating behaviour increased two-fold after the combs with uncapped brood were removed, from 2.3 to 4.6 times per minute, on average (twoway ANOVA: $F_{1,12}=9.95, P=0.008$ : Figure 2 ). There was no significant difference among the colonies (two-way ANOVA: $F_{2,12}=1.34, P=0.299$ ) in the wing-beating behaviour of workers. The interaction between experimental treatments and colonies was also insignificant (two-way ANOVA: $F_{2,12}=1.33, P=0.300$ ).

\subsection{Characteristics of wing-beating behaviour}

A comparison of the characteristics of wing beating (i.e. frequency of wing beats, duration of one wing-beating pulse and interval duration

\section{Table I}

The incidence of wing-beating behaviour performed by workers in contact with the queen and the egg-laying rate of queens in three honey bee colonies before and after removing the combs with uncapped brood from the nests

\begin{tabular}{|c|c|c|c|c|c|c|c|}
\hline \multirow[t]{2}{*}{ Uncapped brood } & \multirow[t]{2}{*}{$\begin{array}{l}\text { Day of the } \\
\text { experiment }\end{array}$} & \multicolumn{3}{|c|}{$\begin{array}{l}\text { The incidence of wing-beating } \\
\text { behaviour (behaviours/minute) }\end{array}$} & \multicolumn{3}{|c|}{ The egg-laying rate (eggs/minute) } \\
\hline & & Colony A & Colony B & Colony $\mathrm{C}$ & Colony A & Colony B & $\begin{array}{l}\text { Colony } \\
\text { C }\end{array}$ \\
\hline \multirow[t]{3}{*}{ Present } & 1 & 1.44 & 2.07 & 3.58 & 1.00 & 0.57 & 0.09 \\
\hline & 2 & 1.59 & 1.51 & 1.44 & 1.04 & 1.21 & 0.20 \\
\hline & 3 & 1.93 & 0.69 & 6.15 & 0.75 & 0.93 & 0.28 \\
\hline \multirow[t]{3}{*}{ Absent } & 4 & 7.83 & 5.15 & 6.78 & 0.47 & 0.20 & 0.29 \\
\hline & 5 & 4.03 & 3.11 & 3.73 & 0.43 & 1.28 & 0.35 \\
\hline & 6 & 4.63 & 3.36 & 3.16 & 0.83 & 0.12 & 0.23 \\
\hline
\end{tabular}




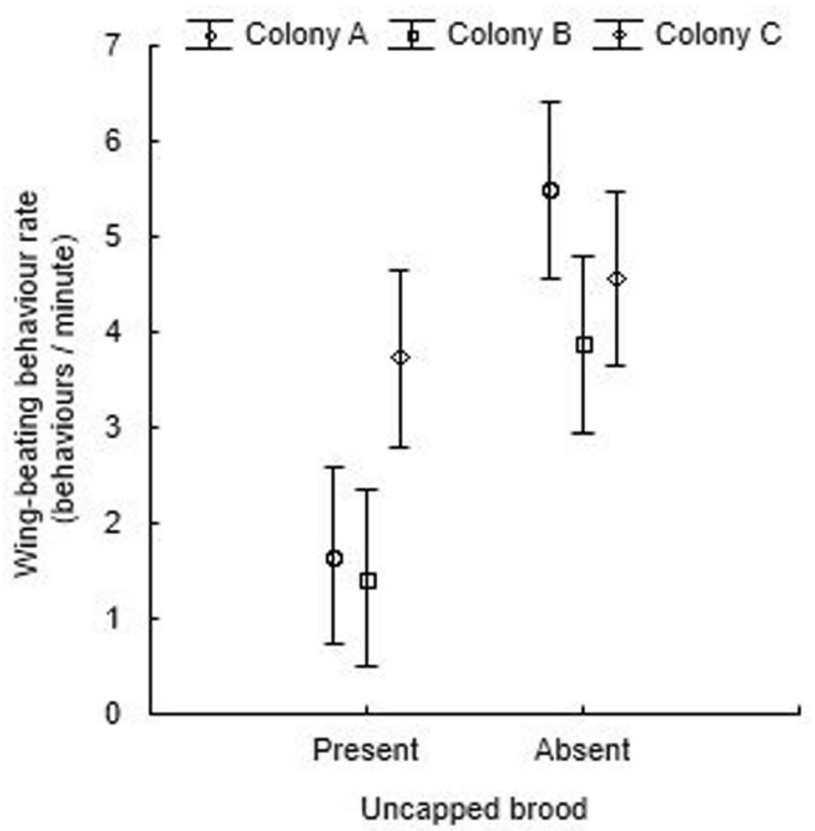

Figure 2. The mean $( \pm$ SE) incidence of wing-beating behaviour produced by workers in contact with the queen.

between wing-beating pulses) performed by workers in the presence of the queen revealed an insignificant difference before and after removing the combs with uncapped brood from the nest (two-way MANOVA: $F_{3,121}=1.46, P=0.228$ ). However, there were significant differences among the colonies (two-way MANOVA: $\left.F_{6,242}=4.97, P<0.001\right)$. The interaction between experimental treatments and colonies was insignificant (two-way MANOVA: $F_{6,242}=2.03$, $P=0.062)$.

The frequency of wing beats was similar before and after the combs with uncapped brood were removed from the nest (Table II). However, the interaction between experimental treatments and colonies was significant. There was also significant difference among the colonies. Workers in Colony $\mathrm{C}$ moved their wings with significantly higher frequency than

\section{Table II}

The mean $( \pm \mathrm{SD})$ values and the results of univariate tests of two-way MANOVA comparing the characteristics of wing-beating based on wing-beating behaviours performed by workers in the presence and absence of uncapped brood

\begin{tabular}{|c|c|c|c|c|c|}
\hline \multirow[t]{2}{*}{ Variables } & \multicolumn{2}{|c|}{ Uncapped brood } & \multicolumn{3}{|c|}{ Source of variation } \\
\hline & $\begin{array}{l}\text { Present } \\
\text { Mean } \pm \text { SD }\end{array}$ & $\begin{array}{l}\text { Absent } \\
\text { Mean } \pm \text { SD }\end{array}$ & Treatment & Colony & Interaction \\
\hline Frequency of wing beats $(\mathrm{Hz})$ & $205.5 \pm 55.42$ & $204.1 \pm 46.18$ & $\begin{array}{l}F_{1,12}=2.50 \\
P=0.117\end{array}$ & $\begin{array}{l}F_{2,12}=10.62 \\
\boldsymbol{P}<\mathbf{0 . 0 0 1}\end{array}$ & $\begin{array}{l}F_{2,12}=5.58 \\
\boldsymbol{P}=\mathbf{0 . 0 0 5}\end{array}$ \\
\hline $\begin{array}{l}\text { Duration of one wing-beating pulse } \\
(\mathrm{ms})\end{array}$ & $53.1 \pm 29.82$ & $53.9 \pm 25.61$ & $\begin{array}{l}F_{1,12}=1.00 \\
P=0.318\end{array}$ & $\begin{array}{l}F_{2,12}=3.58 \\
\boldsymbol{P}=\mathbf{0 . 0 3 1}\end{array}$ & $\begin{array}{l}F_{2,12}=0.25 \\
P=0.778\end{array}$ \\
\hline $\begin{array}{l}\text { Interval duration between wing- } \\
\text { beating pulses (ms) }\end{array}$ & $74.9 \pm 66.42$ & $100.8 \pm 92.38$ & $\begin{array}{l}F_{1,12}=3.70 \\
P=0.057\end{array}$ & $\begin{array}{l}F_{2,12}=1.41 \\
P=0.248\end{array}$ & $\begin{array}{l}F_{2,12}=1.03 \\
P=0.360\end{array}$ \\
\hline
\end{tabular}


workers in Colony A or Colony B (NIR Fisher test: $P<0.001$ and $P=0.017$, respectively).

The duration of wing-beating pulses was similar before and after the combs with uncapped brood were removed from the nest (Table II). The interaction between experimental treatments and colonies was insignificant. However, the colonies significantly differed in the duration of wing-beating pulses. The pulses of wing beating produced by workers in Colony $\mathrm{C}$ lasted significantly longer than those produced by workers in Colony A (NIR Fisher test: $P=0.009$ ).

The interval duration between pulses of wingbeating was similar before and after the removal of combs with uncapped brood from the nest (Table II), although the difference was marginally insignificant. There was an insignificant difference among colonies in terms of interval duration, and the interaction between experimental treatments and colonies was also insignificant.

\subsection{Egg-laying rate}

In the presence of uncapped brood, the queens from Colonies A and B laid one egg per minute on average. However, the queen from Colony
C laid only one egg every 5 min on average (Table I). The egg-laying rate of the queens did not significantly change after removal of combs with uncapped brood from the nest (two-way ANOVA: $\left.F_{1,12}=1.92, P=0.191\right)$. However, the behaviour of the queens did significantly differ among the colonies (two-way ANOVA: $F_{2,12}=4.89, P=0.028$ : Figure 3). The post hoc test showed that the behaviour of the queen from Colony $\mathrm{C}$ was significantly different in comparison with that of the queens from Colonies $\mathrm{A}$ and B (NIR Fisher test: $P=0.016$ and $P=0.023$, respectively). The interaction between experimental treatments and colonies was insignificant (two-way ANOVA: $F_{2,12}=1.06, P=0.378$ ).

\section{DISCUSSION}

The results presented here indicate that honey bee workers showed wing-beating behaviour in contact with the queen significantly more often after the combs with uncapped brood were removed from the nest, which is in line with our predictions. We hypothesised that this behaviour is used by workers to stimulate



Figure 3. The mean ( \pm SE) egg-laying rate of queens. 
the queen to lay eggs at a higher rate in response to too small amount of brood in the colony. In contrast to the queen, workers can more easily obtain information about the colony's ability to raise brood because they are responsible for feeding and caring for the larvae (Seeley 1995). Workers nursing larvae and attending the queen are in the same age group (Allen 1955, 1960; Seeley 1979, 1995), and most likely perform those tasks interchangeably. Workers only remain in the queen's retinue for a short time (Allen 1955, 1960; Seeley 1979), and it is most likely that they have previously attended to larvae and know how well they are nourished. Unfortunately, our recordings were too short to determine the behaviour of the workers before or after the wing-beating behaviour.

Contrary to our expectations, the queen's egg-laying rate did not increase after uncapped brood was removed from the nest. We suspect that this may be related to colony disturbance and the introduction of non-natal combs with a foreign odour. We observed that the largest decrease in egg-laying rate occurred on the day the combs with uncapped brood were removed from the nest, and that on subsequent days, the egg-laying rate recovered. In some studies, a hive inspection did not affect workers' foraging (Free and Spencer-Booth 1963), but in others, an inspection resulted in weight loss of the inspected colony (Taber 1963). It is also known that the use of smoke affects the behaviour of workers (Newton 1969). Moreover, the wax combs are very important in the maintenance of colony odour (Breed 1998; D'Ettorre et al. 2006). Therefore, our experimental manipulation may have resulted in a disturbance in the behaviour of queens and workers. The influence of hive inspection and comb replacement on queen behaviour has not been studied yet. It is also possible that the egg-laying rate cannot increase too quickly and that such a change requires more than 3 days. Presumably, more complex approach would be advisable including observations not only the wing-beating behaviour of workers, but also their other behaviours directed to the queen such as feeding.
It cannot be excluded that the observed differences in wing-beating behaviour of workers in contact with the queen were also related to the colony disturbance and the introduction of non-natal combs. However, it is very likely that the significantly increased incidence of wingbeating behaviour was caused by a lack of uncapped brood in the nest and the lower egglying rate of the queens. This is to some degree supported by observations of the queen and workers in Colony $\mathrm{C}$, which behaved differently than those in Colonies A and B. In Colony C, the queen laid fewer eggs in comparison with the other two queens, in both the presence and absence of uncapped brood in the nest. Presumably, the low quality or advanced age of this queen was responsible for her low egg-laying rate. Unfortunately, the age and health status of queens were unknown. Importantly, the workers in Colony $\mathrm{C}$ reacted to their queen's egglaying behaviour and presented a significantly higher incidence of wing-beating behaviour than those in Colonies A and B. This difference was clearly visible before the removal of combs with uncapped brood from the nest. Workers from Colony A and B also increased the incidence of wing-beating behaviour in the absence of uncapped brood, and this increase was continuing during 3 days after the removal of combs. Those observations suggest that the wing-beating behaviour generated by workers in contact with the queen may inform her about too small amount of uncapped brood and the necessity to lay eggs at a higher rate, and is not only a result of disturbing the colony. Previously, it was also reported that the frequency of shaking signals and piping signals performed by workers on queens during swarming period was increasing along with the approaching day of a swarm departure (Allen 1958, 1959; Painter-Kurt and Schneider 1998a; Pierce et al. 2007). The meaning of these behaviours is not fully understood; however, it is suggested that their role is to prepare a laying queen for flight (Allen 1958, 1959). During this time, workers also decreased the rate of feeding of the queen (Allen 1960). 
The detailed analysis of the wing-beating behaviour of workers attending the queen did not reveal any significant differences in the frequency of wing beats, the duration of wing-beating pulses or the interval between wing-beating pulses before and after the removal of combs with uncapped brood from the nest. Presumably, the characteristics of wing vibrations are not as important for honey bee communication as the incidence of wing-beating behaviour and the social context in which this behaviour occurs. Previous research showed that the frequency of wing beats and the durations of wing-beating pulses generated by queens, drones and workers differed considerably (Łopuch and Tofilski 2019). However, the characteristics of wing vibrations produced by workers during different social interactions with the queen, drones or other workers were less variable, ranging from 100 to $500 \mathrm{~Hz}$ and lasting from 0.5 to 3 s (Ohtani and Kamada 1980; Michelsen et al. 1986a; Nieh 1993; Pratt et al. 1996; Seeley and Tautz 2001; Rangel and Seeley 2008; Rittschof and Seeley 2008; Schlegel et al. 2012; Łopuch and Tofilski 2019).

\section{CONCLUSIONS}

The wing-beating behaviour of workers from the queen's retinue was more frequent in the absence of uncapped brood in the nests. However, during 3 days after the combs removal, we were not able to detect significant increase of egg laying by the queen. Colony disturbance and too short time for the queen to increase the egglaying rate could be responsible for this result. Therefore, further research is required to determine whether or not the wing-beating behaviour of workers may affect the queens' egg-laying rate.

\section{SUPPLEMENTARY INFORMATION}

The online version contains supplementary material available at https://doi.org/10.1007/s13592-021-00905-2.

\section{ACKNOWLEDGEMENTS}

We also thank the anonymous reviewers for their suggestions and comments.

\section{AUTHOR CONTRIBUTION}

SL and AT contributed to the study conception and design. Data collection and analysis were performed by SL. The first draft of the manuscript was written by SL. SŁ and AT commented on previous versions of the manuscript. Both authors read and approved the final manuscript.

\section{FUNDING}

This study was funded by the National Science Centre under grant DEC-2013/10/E/NZ9/00682.

\section{DATA AVAILABILITY}

The datasets generated during and/or analysed during the current study are available from the corresponding author on reasonable request.

\section{DECLARATIONS}

Ethical approval Not applicable.

Consent to participate Not applicable.

Consent for publication Not applicable.

Conflict of interest The authors declare no competing interests.

Open Access This article is licensed under a Creative Commons Attribution 4.0 International License, which permits use, sharing, adaptation, distribution and reproduction in any medium or format, as long as you give appropriate credit to the original author(s) and the source, provide a link to the Creative Commons licence, and indicate if changes were made. The images or other third party material in this article are included in the article's Creative Commons licence, unless indicated otherwise in a credit line to the material. If material is not included in the article's Creative Commons licence and your intended use is not permitted by statutory regulation or exceeds the permitted use, you will need to obtain permission directly from the copyright holder. To view a copy of this licence, visit http://creativecommons.org/licenses/by/4.0/.

\section{REFERENCES}

Alaux, C., Maisonnasse, A., Le, Conte, Y. (2010) Pheromones in a superorganism: from gene to social regulation. Vitam Horm 83, 401-423. doi: https:// doi.org/10.1016/S0083-6729(10)83017-1 
Allen, M.D. (1955) Observations on honeybees attending their queen. Brit J Anim Behav 3, 66-69. doi:https://doi.org/10.1016/S0950-5601(55) 80015-9

Allen, M.D. (1958) Shaking of honey bee queens prior to flight. Nature 181, 68. doi:https://doi.org/10. 1038/181068a0

Allen, M.D. (1959) The occurrence and possible significance of the "shaking", of honeybee queens by the workers. Anim Behav 7, 66-69. doi:https://doi.org/ 10.1016/0003-3472(59)90032-6

Allen, M.D. (1960) The honeybee queen and her attendants. Anim Behav 8, 201-208. doi:https://doi.org/ 10.1016/0003-3472(60)90028-2

Bortolotti, L., Costa, C. (2014) Chemical communication in the honey bee society. In: Neurobiology of chemical communication. CRC Press/Taylor \& Francis.

Breed, M.D. (1998) Recognition pheromones of the honey bee. BioScience 48, 463-470. doi:https:// doi.org/10.2307/1313244

D'Ettorre, P., Wenseleers, T., Dawson, J., Hutchinson, S., Boswell, T., Ratnieks, F.L. (2006) Wax combs mediate nestmate recognition by guard honeybees. Anim Behav 71, 773-779. doi:https://doi.org/10. 1016/j.anbehav.2005.05.014

Esch, H., Wilson, D. (1967) The sounds produced by flies and bees. Z Vergl Physiol 54, 256-267. doi:https://doi.org/10.1007/BF00298031

Free, J.B., Spencer-Booth, Y. (1963) The Effect of Examining Honeybee Colonies on their Subsequent Foraging Activity. J Apic Res 2, 67-68. doi:https:// doi.org/10.1080/00218839.1963.11100060

Free, J.B., Williams, I.H. (1972) The influence of a honeybee (Apis mellifera) colony on egg-laying by its queen. Entomol Exp Appl 15, 224-228. doi:https:// doi.org/10.1111/j.1570-7458.1972.tb00200.x

Gahl, R.A. (1975) The shaking dance of honey bee workers: evidence for age discrimination. Anim Behav 23, 230-232. doi:https://doi.org/10.1016/ 0003-3472(75)90068-8

Grooters, H.J. (1987) Influences of queen piping and worker behaviour on the timing of emergence of honey bee queens. Insect Soc 34, 181-193. doi:https://doi.org/10.1007/BF02224083

Guidelines for the use of Animals (2020) Guidelines for the treatment of animals in behavioural research and teaching. Anim Behav 159, i-xi. doi:https:// doi.org/10.1006/anbe.1996.0293

Hrncir, M., Barth, F.G., Tautz, J. (2006) Vibratory and airborne-sound signals in bee communication (Hymenoptera). Insect sounds and communication. CRC Press, pp 421-436.

Hrncir, M., Gravel, A.I., Schorkopf, D.L.P., Schmidt, V.M., Zucchi, R., Barth, F.G. (2008) Thoracic vibrations in stingless bees (Melipona seminigra): resonances of the thorax influence vibrations associated with flight but not those associated with sound production. J Exp Biol 211, 678-685. doi:https://doi.org/10.1242/jeb.013920

Hunt, J.H., Richard, F.J. (2013) Intracolony vibroacoustic communication in social insects. Insect Soc 60, 403-417. doi:https://doi.org/10.1007/ s00040-013-0311-9

Kirchner, W.H. (2006) Acoustical communication in social insects. Orientation and communication in arthropods. Ed. Lehrer M. Birkhäuser Verlag Basel, Switzerland.

Koeniger, G. (1986) Reproduction and mating behavior. Bee genetics and breeding. Ed. Rinderer TE. Academic Press, pp. 255-280.

Le Conte, Y., Arnold, G., Trouiller, J., Masson, C. (1990) Identification of a brood pheromone in honeybees. Naturwissenschaften 81:432-465. doi:https://doi.org/10.1007/BF01138390

Le Conte, Y., Mohammodi, A., Robinson, G.E. (2001) Primer effects of a brood pheromone on honeybee behavioural development. Proc R Soc Lond B 268, 1-6. doi:https://doi.org/10.1098/rspb.2000.1345

Łopuch, S., Tofilski, A. (2017a) Direct visual observation of wing movements during the honey bee waggle dance. J Insect Behav 30, 199 210. doi:https:// doi.org/10.1007/s10905-017-9610-8

Łopuch, S., Tofilski, A. (2017b) Importance of wing movements for information transfer during honey bee waggle dance Ethology 123, 974-980. doi:https://doi.org/10.1111/eth.12703

Łopuch, S., Tofilski, A. (2019) Use of high-speed recording to detect wing beating produced by honey bees. Insect Soc 66, 235-244. doi:https:// doi.org/10.1007/s00040-018-00678-5

Łopuch, S., Tofilski, A. (2020) Impact of the quality of food sources on the wing beating of honey bee dancers. Apidologie 51, 631-641. doi:https://doi. org/10.1007/s13592-020-00748-3

Metz, B.N., Pankiw, T., Tichy, S.E., Aronstein, K.A., Crewe, R.M. (2010) Variation and responses to brood pheromone of the honey bee (Apis mellifera L.). J Chem Ecol 36, 432-440. doi:https://doi.org/ 10.1007/s10886-010-9775-5

Michelsen, A., Kirchner W.H., Lindauer. M. (1986a) Sound and vibrational signals in the dance language of the honeybee, Apis mellifera Behav Ecol Sociobiol 18, 207 212. doi:https://doi.org/10.1007/ BF00290824

Michelsen, A., Kirchner, W.H., Andersen, B.B., Lindauer, M. (1986b) The tooting and quacking vibration signals of honeybee queens: a quantitative analysis J Comp Physiol A 158, 605 601. doi:https:// doi.org/10.1007/BF00603817

Michelsen, A., Towne, W.F., Kirchner, W.H., Kryger, P. (1987) The acoustic near field of a dancing honeybee. J Comp Physiol A 161, 633-643. doi:https://doi.org/ 10.1007/BF00605005

Newton, D.C. (1969) Behavioural response of honeybees to colony disturbance by smoke. II. Guards and foragers. J 
Apic Res 8:79-82. doi:https://doi.org/10.1080/00218839. 1969.11100222

Nieh, J.C. (1993) The stop signal of honey bees: reconsidering its message. Behav Ecol Sociobiol 33, 51-56. doi:https://doi.org/10.1007/BF00164346

Ohtani, T., Kamada, T. (1980) Worker piping: the piping sounds produced by laying and guarding worker honeybees. J Apic Res 19, 154-163

Painter-Kurt, S., Schneider, S. (1998a) Age and behavior of honey bees, Apis mellifera (Hymenoptera: Apidea), that perform vibration signals on queens and queen cells Ethology 104, 475 485. doi:https:// doi.org/10.1111/j.1439-0310.1998.tb00084.x

Painter-Kurt, S., Schneider, S. (1998b) Age and behavior of honey bees, Apis mellifera (Hymenoptera: Apidea), that perform vibration signals on workers. Ethology 104, 457-473. doi:https://doi.org/10. 1111/j.1439-0310.1998.tb00083.x

Pankiw, T., Page, R.E., Fondrk, M.K. (1998) Brood pheromone stimulates pollen foraging in honey bees (Apis mellifera). Behav Ecol Sociobiol 44, 193-198. doi:https://doi.org/10.1007/s002650050531

Pierce, A.L., Lewis, L.A., Schneider, S. (2007) The use of the vibration signal and worker piping to influence queen behavior during swarming in honey bees, Apis mellifera. Ethology 113, 267275. doi:https://doi.org/10.1111/j.1439-0310.2006. 01314.x

Pratt, S.C., Kühnholz, S., Seeley, T.D., Weidenmüller, A. (1996) Worker piping associated with foraging in undisturbed queenright colonies of honey bees. Apidologie 27, 13-20. doi:https://doi.org/10.1051/ apido:19960102

Ramsey, M., Bencsik, M., Newton, M.I. (2017) Longterm trends in the honeybee 'whooping signal' revealed by automated detection. PlosOne 12, e0171162. https://doi.org/10.1371/journal.pone. 0181736

Ramsey, M.T., Bencsik, M., Newton, M.I., Reyes, M., Pioz, M., Crauser, D., Delso, N.S., Le Conte, Y. (2020) The prediction of swarming in honeybee colonies using vibrational spectra. Sci Rep 10, 9798. https://doi.org/10.1038/s41598-020-66115-5

Rangel, J., Seeley, T.D. (2008) The signals initiating the mass exodus of a honeybee swarm from its nest. Anim Behav 76, 1943-1952. doi:https://doi.org/ 10.1016/j.anbehav.2008.09.004

Richard, F.J., Hunt, J.H. (2013) Intracolony chemical communication in social insects. Insect Soc 60, 275-291. doi:https://doi.org/10.1007/ s00040-013-0306-6

Rittschof, C.C., Seeley, T.D. (2008) The buzz-run: how honeybees signal 'Time to go!' Anim Behav 75, 189-197. doi:https://doi.org/10.1016/j.anbehav. 2007.04.026

Sagili, R.R., Pankiw, T. (2009) Effects of brood pheromone modulated brood rearing behaviors on honey bee (Apis mellifera L.) colony growth. J Insect
Behav 22, 339-349. doi:https://doi.org/10.1007/ s10905-009-9176-1

Schlegel, T., Visscher, P.K., Seeley, T.D. (2012) Beeping and piping: characterization of two mechanoacoustic signals used by honey bees in swarming. Naturwissenschaften 99, 1067-1071. doi:https:// doi.org/10.1007/s00114-012-0990-5

Seeley, T.D. (1979) Queen substance dispersal by messenger workers in honeybee colonies. Behav Ecol Sociobiol 5, 391-415. doi:https://doi.org/10.1007/ BF00292527

Seeley, T.D. (1995) The wisdom of the hive. The social physiology of honey bee colonies. Cambridge. MA: Harvard University Press.

Seeley, T.D., Tautz, J. (2001) Worker piping in honey bees swarms and its role in preparing for liftoff. J Comp Physiol A 187, 667-676. doi:https://doi.org/10.1007/ s00359-001-0243-0

Seeley, T.D., Visscher, P.K. (2008) Sensory coding of nest-site value in honeybee swarms. J Exp Biol 211, 3691-3697. doi:https://doi.org/10.1242/jeb. 021071

Simpson, J. (1964) The mechanism of honey-bee queen piping. Z Vergl Physiol 48, 277-282

Slessor, K.N., Winston, M.L., Le Conte, Y. (2005) Pheromone communication in the honeybee (Apis mellifera L.). J Chem Ecol 31, 2731-2745. doi:https://doi.org/10.1007/s10886-005-7623-9

Statsoft Inc. (2017) Statistica (data analysis software system), version 13.3. http://www.statsoft.com. Accessed 08 June 2021 Vision Research Inc. (2015) PCC software, version 2.6. http://www. visionresearch.net. Accessed 08 June 2021

Taber, S. (1963) The effect of disturbance on the social behaviour of the honey bee colony. Am Bee J 103, 286-288.

Tautz, J. (1996) Honeybee waggle dance: recruitment success depends on the dance floor. J Exp Biol 199, 1375-1381. doi:https://doi.org/10.1242/jeb. 199.6.1375

Traynor, K., Le Conte, Y., Page, R.E. (2014) Queen and young larval pheromones impact nursing and reproductive physiology of honey bee (Apis mellifera) workers. Behav Ecol Sociobiol 68, 2059-2073. doi:https://doi.org/10.1007/s00265-014-1811-y

Traynor, K., Le Conte, Y., Page, R.E. (2015) Age matters: pheromone profiles of larvae differentially influence foraging behaviour in the honeybee, Apis mellifera. Anim Behav 99, 1-8. doi:https://doi.org/ 10.1016/j.anbehav.2014.10.009

Vision Research Inc. (2015) PCC software, version 2.6. http://www.visionresearch.net. Accessed 08 June 2021

Waddington, K.D., Kirchner, W.H. (1992) Acoustical and behavioral correlates of profitability of food sources in honey bee round dances. Ethology 92, 1-6. doi:https://doi.org/10.1111/j.1439-0310.1992. tb00945.x 
Wenner, A.M. (1962a) Communication with queen honey bee by substrate sound Science 138, 446448. https://doi.org/10.1126/science.138.3538.446

Wenner, A.M. (1962b) Sound production during the waggle dance of the honey bee Anim Behav 10, 79-95. doi:https://doi.org/10.1016/0003-3472(62) 90135-5

Wenner, A.M., Wells, P.H., Rohlf, F.J. (1967) An analysis of the waggle dance and recruitment in honey bees. Physiol Zool 40, 317-344. doi:https://doi. org/10.1086/physzool.40.4.30158452

Publisher's Note Springer Nature remains neutral with regard to jurisdictional claims in published maps and institutional affiliations. 